\title{
Nutritive value of rapeseed meals and cakes for pigs and sheep
}

\author{
MAIJA-LIISA SALO
}

Department of Animal Husbandry, University of Helsinki, 00710 Helsinki
71, Finland

Abstract. Digestibility and nutritive value for growing pigs, liveweight $40-70 \mathrm{~kg}$, were determined for high glucosinolate (HG) Span and Torch (Brassica campestris) rapeseed meals (RSM) and cakes (RSC), and for low glucosinolate (LG) Regent (B. napus) RSM and DF-15 (B. campestris) RSC in barley based diets in one year or two successive years. Some of the feeds were evaluated also for sheep. The level of RSM and RSC was 20 or $30 \%$ of diets for pigs and $32 \%$ for sheep.

The observed net energy value of commercial Span-Torch RSM for pigs was in two successive years 0.80 and 0.79 f.u. $/ \mathrm{kg}$ dry matter $(\mathrm{DM})$ ( f.u. $=$ feed unit $=0.7 \mathrm{~kg}$ starch equivalent). The protein values were 281 and $291 \mathrm{~g}$ digestible crude protein (DCP)/ $\mathrm{kg} \mathrm{DM}$, respectively. The $8 \%$-units higher fat content together with a little better digestibility of organic components raised the f.u. value of RSC about $30 \%$ above that of RSM. For pigs there were only slight differences in the digestibility and palatability of the HG Span-Torch and the LG Regent and DF-15 meals and cakes, but there was a clear difference in the palatability in successive years. The nitrogen balances for pigs on the RSM or RSC and barley diets were 20.4-22.2 g N/d, and the biological values of protein of the RSM and RSC were 67-68.

The net energy value of Span-Torch rapeseed meal for sheep was $0.91 \mathrm{f} . \mathrm{u} . / \mathrm{kg} \mathrm{DM}$, and the protein value $309 \mathrm{~g} \mathrm{DCP} / \mathrm{kg}$ DM. The digestibility of cakes was nearly equal to meal, but the $8 \%$-units higher fat content raised the f.u. value of RSC about $20 \%$. The digestibility of organic matter of LG DF-15 cakes was a little better $(P<0.05)$ than that of Span-Torch cakes. The sheep willingly ate RSM and RSC at a 32 $\%$ level of the diets.

\section{Introduction}

Numerous experiments have indicated that the energy value of rapeseed meal (RSM) is lower than soybean meal for pigs (e.g. McKINNON and BOWLAND 1977, KENNELLY et al. 1978, AHERNE and LEWIS 1978, ALAVIUHKOLA 1979); conflicting results have been found for ruminants (WOOD and STONE 1979, STAKE et al. 1973, SHARMA et al. 1980). The digestibility of RSM protein is poorer for both animal species. The nutritive value of RSM varies with the cultivar, the glucosinolate content, environmental conditions and processing methods (BELL et al. 1976).

Most recent studies have been concerned with low glucosinolate (LG) RSM. In Finland, however, climate imposes a preference for the high glucosinolate (HG) Brassica campestris cultivars (cv. Span and Torch).

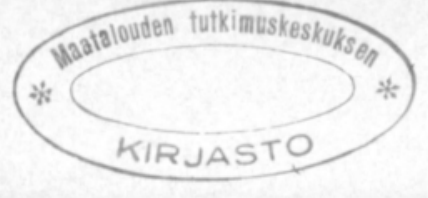


The objective of the present study was to evaluate domestic pre-pressed, solvent-extracted rapeseed meals for growing pigs and sheep and compare them with rapeseed cakes (RSC), as well as with meals and cakes prepared from some newer rapeseed varieties.

\section{Materials and methods}

Feeds

The chemical compositions of the investigated RSM and RSC are presented in Table 1. Span and Torch varieties are widely cultivated in southern Finland. Since the meals are not marketed separately and are much alike in chemical composition, they are expressed here as "Span-Torch". Samples represented commercial RSM, originating from different processing plants in different years. The Span-Torch cakes were of the same origin as meals, differing only in being pressed. DF-15 (B. campestris) and Regent (B. napus) are LG varieties, grown at research stations. The former was only pressed, the latter also slightly extracted. According to information supplied by the processor the glucosinolate content of the seeds of Span and Torch is about 3 $\%$, that of DF-15 about $1.5 \%$ and of Regent $<1 \%$. The most goitrogenic component, oxazolidinethione, comprises about $65 \%$ of the glucosinolate hydrolysis products of Regent, but only about $30 \%$ of those of $B$. campestris varieties. The tannin content of rapeseed meals is $2-3 \%$.

\section{Experiments with pigs}

The digestibility and balance trials were performed with growing pigs, which were fed according to the energy standards scale of PARTANEN (1970). Barley meal was used as the basic feed and the diets were supplemented with minerals and vitamins as recommended in standards.

The first experiment (1979) was carried out with four barrows, weighing during collecting periods $50-70 \mathrm{~kg}$. The RSM comprised $30 \%$ of the diets.

The second experiment (1980) was carried out with three barrows, of liveweight $40-70 \mathrm{~kg}$, using a $3 \times 3$ Latin square design. The palatability of RSM was very poor in 1980 , and the proportion of RSM in the diets had therefore to be restricted to $20 \%$.

The pigs were kept in metabolic cages allowing a separate collection of faeces and urine. The adaptation period before the first trial was about three weeks, the transition period 3-5 days, and both the standardization and collection periods 7 days.

The animals were fed twice daily. The different ingredients were weighed separately and mixed with two volumes of water. Water was given freely after feeding. The faeces and urine were collected in the morning and samples of fixed amount were taken for analysis and stored frozen until analyzed. Sulphuric acid was added to the urine collection pail to keep the acidity under 
$\mathrm{pH}$ 3. Feed spillages were collected and subtracted from the given feed. The pigs were weighed before and after the collection period.

Dry matter determinations were made at $103^{\circ} \mathrm{C}$, and the samples for analysis dried in vacuum at $50^{\circ} \mathrm{C}$. Feeds and faeces were ground through a 0.5 $\mathrm{mm}$ screen. The analyses were made according to standard procedures.

The digestibility of barley was determined by separate trial in each year and the digestibility of the RSM and RSC calculated by subtraction.

The net energy values (f.u. $=$ feed unit $=0.7 \mathrm{~kg}$ starch equivalent) were calculated using factors and models of NJF Feed Tables (ANON. 1969). The results were tested by one-way variance analysis and the differences between means by the Tukey-test (STEELE and TORRIE 1960).

\section{Experiments with sheep}

Sheep trials were performed with three rams, average weight $45 \mathrm{~kg}$, as a $3 \times 3$ Latin square design. The trials consisted of transition, standardization and collection periods, each of them lasting 7 days.

The animals were kept in cages with a funnel for the collection of urine. During the collection period the sheep were provided with faeces-collecting harnesses.

The feeding took place twice daily. Basic feed was $400 \mathrm{~g}$ hay and $250 \mathrm{~g}$ barley meal/d, plus minerals and vitamins according to standards. Hay and barley were of normal quality and their digestibilities were determined by separate trials. Amounts of RSM and RSC (Table 1) were $300 \mathrm{~g} / \mathrm{d}$ (32\% of the diet). Water was unrestricted and its consumption was measured. The sheep were weighed before and after the collection period.

Otherwise the experimental technique and the calculation of the results were essentially the same as for pigs.

\section{Results and discussion}

\section{Experiments with pigs}

The commercial RSM has been evaluated for pigs in three successive years, the first study being reported in a earlier paper (SALO 1980). The results show the chemical composition and digestibility and thus the nutritive value of the domestic RSM to be approximately constant (Tables 1, 2 and 3). The observed net energy values for pigs in three successive years were 0.78 , 0.80 and $0.79 \mathrm{f}$.u. $/ \mathrm{kg} \mathrm{DM}$, and the protein values 248,281 and $291 \mathrm{~g} \mathrm{DCP} / \mathrm{kg}$ $\mathrm{DM}$, respectively. The digestibility of organic matter was equal to that reported in the Feed Tables of Sweden (ERIKSSON et al. 1972) and Denmark (ANDERSEN and JUST 1979), but a little lower than the corresponding data in Feed Tables of Norway (BREIREM and HOMB 1970) and the Netherlands (ANON. 1979). The found digestibility of protein was slightly lower than that of the same feed tables. 
Table 1. Chemical composition of rapeseed meals and cakes, $\%$ of dry matter.

\begin{tabular}{lccccc}
\hline Rapeseed meals and cakes & $\begin{array}{c}\text { Crude } \\
\text { protein }\end{array}$ & $\begin{array}{c}\text { Ether } \\
\text { extract }\end{array}$ & $\begin{array}{c}\text { Crude } \\
\text { fibre }\end{array}$ & Ash & $\begin{array}{c}\text { N-free } \\
\text { extract }\end{array}$ \\
\hline $\begin{array}{l}\text { Exp. 1: Pigs } \\
\text { Span-Torch, meal }\end{array}$ & 37.9 & 2.8 & 14.2 & 8.2 & 36.9 \\
Regent, meal & 38.0 & 8.3 & 13.7 & 7.8 & 32.2 \\
Exp. 2: Pigs and sheep & & & & & \\
$\begin{array}{l}\text { Span-Torch, meal } \\
\quad \text { cakes }\end{array}$ & 37.6 & 2.4 & 14.8 & 8.0 & 37.2 \\
DF-15, cakes & 33.6 & 10.4 & 15.7 & 7.4 & 32.9 \\
\hline
\end{tabular}

Table 2. Digestibility coefficients of rapeseed meals and cakes for pigs.

\begin{tabular}{|c|c|c|c|c|c|}
\hline & \multicolumn{2}{|c|}{ Exp. 1} & \multicolumn{3}{|c|}{ Exp. 2} \\
\hline & $\begin{array}{l}\text { Span-Torch } \\
\text { meal }\end{array}$ & $\begin{array}{c}\text { Regent } \\
\text { meal }\end{array}$ & $\begin{array}{c}\text { Span-Torch } \\
\text { meal }\end{array}$ & $\begin{array}{l}\text { Span-Torch } \\
\text { cakes }\end{array}$ & $\begin{array}{c}\text { DF-15 } \\
\text { cakes }\end{array}$ \\
\hline Organic matter & 64.5 & 64.0 & 66.2 & 72.5 & 76.8 \\
\hline Crude protein & 74.1 & 75.0 & 77.5 & 83.6 & 84.5 \\
\hline Ether extract & $52.4^{c}$ & $77.9^{d}$ & 21.8 & 77.9 & 81.4 \\
\hline Crude fibre & 32.0 & 26.7 & 39.7 & 48.8 & 58.5 \\
\hline $\mathrm{N}$-free extract & 67.2 & 62.3 & 71.4 & 72.7 & 76.4 \\
\hline
\end{tabular}

In all tables the significance of differences in the same experiment are:

$\mathrm{P}<0.05=\mathrm{a}, \mathrm{b} ; \mathrm{P}<0.01=\mathrm{c}, \mathrm{d}$

Table 3. Net energy and digestible crude protein (DCP) values for pigs, and nitrogen balances in the trials.

\begin{tabular}{|c|c|c|c|c|c|}
\hline & \multicolumn{2}{|c|}{ Exp. 1} & \multicolumn{3}{|c|}{ Exp. 2} \\
\hline & $\begin{array}{l}\text { Span-Torch } \\
\text { meal }\end{array}$ & $\begin{array}{c}\text { Regent } \\
\text { meal }\end{array}$ & $\begin{array}{l}\text { Span-Torch } \\
\text { meal }\end{array}$ & $\begin{array}{l}\text { Span-Torch } \\
\text { cakes }\end{array}$ & $\begin{array}{c}\text { DF-15 } \\
\text { cakes }\end{array}$ \\
\hline Net energy, f.u./kg DM ${ }^{1)}$ & $0.80^{2}$ & $0.90^{b}$ & $0.79^{b}$ & $1.02^{2}$ & $1.04^{2}$ \\
\hline DCP, g/kg DM & 281 & 285 & 291 & 281 & 296 \\
\hline DCP, g/f.u. & 349 & 319 & 359 & 279 & 290 \\
\hline Nitrogen balances, g N/d & 21.0 & 21.4 & 21.3 & 20.4 & 22.2 \\
\hline Biological value & - & - & 67 & 68 & 68 \\
\hline
\end{tabular}

1) f.u. = feed unit $=0.7 \mathrm{~kg}$ starch equivalent

The comparison of RSM and RSC in experiment 2 showed that the net energy value of pressed cakes was nearly $30 \%$ better than that of the pressed and extracted meal (Table 3). Although the principal reason for this difference was the higher content and digestibility of fat, the other feed compo- 
nents, too, were more digestible in cakes. Correspondingly, the slightly extracted Regent RSM of experiment 1 (Table 2) was digested like the commercial extracted RSM, in spite of its high fat content. These results suggest that extraction of rapeseeds slightly impairs the digestibility of meal for pigs. The higher temperature of the extraction phase may be the reason for this effect.

The palatability of RSM appeared to be less constant from one year to the next than the net energy value. The pigs ate the meals and cakes of 1980 less willingly than those of the two preceding years. The reason remained unclear. Perhaps there was a higher content of weed seeds or of some unpalatable constituents of rapeseeds. Between pigs there would hardly be such great differences in taste discrimination.

The nitrogen-balances showed that RSM, as the only protein supplement in barley based diets, was sufficient to satisfy the whole protein synthesizing capacity of barrows. In these experiments as well as in the earlier study (SALO 1980) the N-balances of pigs were $20-22 \mathrm{~g} \mathrm{~N} / \mathrm{d}$, which amount is considered to be the protein synthesis maximum of barrows (WENK et al. 1980). Even 20 $\%$ RSM and RSC of the diet (120-125 g DCP/f.u.) provided essential amino acids in sufficient amount. Furthermore, the N-balances were equally high on the LG (Regent, DF-15) and the HG (Span, Torch) diets. These results are in agreement with the finding of SAUER et al. (1982) that the level of glucosinolates has no effect on the amino acid availabilities to pigs, as well as the results of AHERNE and LEWIS (1980) that the lysine supplement has no benefit for growing pigs fed on a diet that contains LG RSM as the only protein supplement.

\section{Experiments with sheep}

The net energy (f.u.) and DCP values of Span-Torch RSM were higher for sheep than for pigs (Tables 4 and 5), but the f.u. value was still about $20 \%$ below that of soybean meal. The digestibility of organic matter of cakes was only a bit over that of the corresponding meal, but the high fat content made the energy value of cakes comparable with that of extracted soybean meal. The sheep digested the cakes from the LG variety DF-15 a little better $(P<0.05)$ than the cakes from the HG Span-Torch. The observed net energy and DCP values were within the ranges presented for ruminants in the feed tables mentioned above.

In contrast to pigs, which ate the RSM and RSC of experiment 2 very unwillingly, even though concentration was only $20 \%$ of the diet, the sheep readily ate the same RSM and RSC at a $32 \%$ level. The RSM thus causes no consumption problems with ruminants.

In conclusion the present results are in agreement with other experiments with ruminants, which have shown that even HG RSM is a useful protein supplement for growing bulls and high yielding dairy cows (IWARSSON et al. 1973, SHARMA et al. 1977, SYRJÄLÄ-QVIST et als. 1982). For growing pigs, on the other hand, RSM is not as good a protein source, because its palatability 
Table 4. Digestibility coefficients of rapeseed meal and cakes for sheep.

\begin{tabular}{lccc}
\hline & \multicolumn{3}{c}{ Exp. 2 } \\
\cline { 2 - 4 } & $\begin{array}{c}\text { Span-Torch } \\
\text { meal }\end{array}$ & $\begin{array}{c}\text { Span-Torch } \\
\text { cakes }\end{array}$ & $\begin{array}{c}\text { DF-15 } \\
\text { cakes }\end{array}$ \\
\hline Organic matter & $75.0^{\mathrm{b}}$ & $75.6^{\mathrm{b}}$ & $78.8^{\mathrm{a}}$ \\
Crude protein & 82.1 & 82.5 & 83.1 \\
Ether extract & $82.9^{\mathrm{b}}$ & $95.0^{\mathrm{a}}$ & $95.0^{\mathrm{a}}$ \\
Crude fibre & 41.2 & 45.7 & 50.1 \\
N-free extract & 82.0 & 79.0 & 83.8 \\
\hline
\end{tabular}

Table 5. Net energy and DCP values for sheep, and nitrogen balances in the trials.

\begin{tabular}{lccc}
\hline & \multicolumn{3}{c}{ Exp. 2 } \\
\cline { 2 - 4 } & $\begin{array}{c}\text { Span-Torch } \\
\text { meal }\end{array}$ & $\begin{array}{c}\text { Span-Torch } \\
\text { cakes }\end{array}$ & $\begin{array}{c}\text { DF-15 } \\
\text { cakes }\end{array}$ \\
\hline Net energy, f.u./kg DM ${ }^{1)}$ & $0.91^{\mathrm{b}}$ & $1.09^{\mathrm{a}}$ & $1.10^{\mathrm{a}}$ \\
DCP, g/kg DM & 309 & 277 & 291 \\
DCP, g/f.u. & $341^{\mathrm{a}}$ & $255^{\mathrm{b}}$ & $265^{\mathrm{b}}$ \\
Nitrogen balances, g N/d & 2.3 & 2.2 & 2.8 \\
Biological value & 38 & 40 & 41 \\
\hline
\end{tabular}

and digestibility are poorer. The present results agree, nevertheless, with earlier feeding experiments, which have indicated that a quite high concentration of RSM even from the Span and Torch cultivars can be included in the diet of growing-finishing pigs, and still produce good growth results (ALAVIUHKOLA 1979, SALO 1982).

Acknowledgements. I wish to express my warm thanks to Miss Eeva Pekkarinen and Mrs. Eija Helander for their assistance in carrying out the experiments.

\section{References}

AHERNE, F. X. \& LEWIS, A. J. 1978. The nutritive value of Tower rapeseed meal for swine. Anim. Feed Sci. Technol. 3: 235-242.

AHERNE, F. X. \& LEWIS, A. J. 1980. The effect of lysine supplementation of canola meal on pig performance and carcass quality. Canola Council of Canada. Publ. 57: 177-181.

ALAVIUHKOLA, T. 1979. Rapsi- ja rypsijauhot sikojen rehuseoksissa. Käytännön maamies 4/1979: 75-76.

ANDERSEN, P. E. \& JUST, A. 1979. Tabeller over fodermidlers sammensaetning m.m. 56 p. København.

ANON. 1979. Veevoedertabel. 89 p. Nederland.

BELL, J. M., SHARBY, T. F. \& SARWAR, G. 1976. Some effects of processing and seed source on the nutritional quality of rapeseed meal. Can. J. Anim. Sci 56: 809-816. 
BREIREM, K. \& HOMB, T. 1970. Fôrmidler og fôrkonservering. 459 p. Gjøvik.

ERIKSSON, S., SANNE, S. \& THOMKE, S. 1972. Fodermedlen. 299 p. Borås.

IWARSSON, K., EKMAN, L., EVERITT, B. R., FIGUEIRAS, H. \& NILSSON, P. O. 1973. The effect of feeding rapeseed meal on thyroid function and morphology in growing bulls. Acta vet. scand. 14: 610-629.

KENNELLY, J. J., AHERNE, F. X. \& LEWIS, A. J. 1978. The effects of levels of isolation, or varietal differences in high fibre hull fraction of low glucosinolate rapeseed meals on rat or pig performance. Can. J. Anim. Sci. 58: 743-752.

McKINNON, P. J. \& BOWLAND, J. P. 1977. Comparison of low glucosinolate - low erucic acid rapeseed meal (cv. Tower), commercial rapeseed meal and soybean meal as sources of protein for starting, growing and finishing pigs and young rats. Can. J. Anim. Sci. 57: 663-678.

PARTANEN, J. 1970. Lihasikojen uudet viikottaiset ry-normit. Sika 4/1970: 6-18.

SALO, M.-L. 1980. Nutritive value of rapeseed meal from two Brassica campestris varieties for growing pigs. J. Scient. Agric. Soc. Finl. 52: 45-49.

SALO, M.-L. 1982. Rapeseed meal as a protein source for growing pigs. J. Scient. Agric. Soc. Finl. 54: 313-320.

SAUER, W. C., CICHON, R. \& MISIR, R. 1982. Amino acid availability and protein quality of canola and rapeseed meal for pigs and rats. J. Anim. Sci. 54: 292-301.

SHARMA, H. R., INGALLS, J. R. \& DEVLIN, T. J. 1980. Apparent digestibility of Tower of Candle rapeseed meals by Holstein bull calves. Can. J. Anim. Sci. 60: 915-918.

SHARMA, H. R., INGALLS, J. R. \& McKIRDY, J. A. 1977. Effects of feeding a high level of Tower rapeseed meal in dairy rations on feed intake and milk production. Can. J. Anim. Sci. 57: 653-662.

STAKE, P. E., OWENS, M. J. \& SCHINGOETHE, D. J. 1973. Rapeseed, sunflower, and soybean meal supplementation of calf rations. J. Dairy Sci. 56: 783-788.

STEELE, R. G. D. \& TORRIE, J. H. 1960. Principles and procedures of statistics. 481 p. New York.

SYRJÄLÄ-QVIST, L., TUORI, M. \& SETÄLÄ, J. 1982. Rapeseed meal as a protein source for highproduction dairy cows on grass silage and hay-based feeling. J. Scient. Agric. Soc. Finl. 54: $145-153$.

WENK, C., PFIRTER, H. P. \& BICKEL, H. 1980. Energetic aspects of feed conversion in growing pigs. Livest. Prod. Sci. 7: 483-495.

Ms received September 23, 1982

\title{
Rypsi/rapsirouheen ja -kakun rehuarvo sialla ja lampaalla
}

\author{
Maija-Liisa Salo \\ Helsingin yliopiston kotieläintieteen laitos, 00710 Helsinki 71
}

Kotimaisen kaupallisen Span-Torch rypsirouheen ja kakun sekä Regent rapsirouheen ja DF-15 rypsikakun sulavuus ja rehuarvo märitettiin $40-70 \mathrm{~kg}$ painoisilla sioilla yhtenä tai kahtena vuonna. Toisena vuonna samat rehut tutkittiin myös pässeillä. Rouheiden ja kakkujen osuus sioilla oli 30 tai $20 \%$ ohrapohjaisesta dieetistä. Pässeillä rouhetta tai kakkua oli $32 \%$ rehuyhdistelmästä. Span ja Torch ovat runsasglukosinolaattisia, Regent ja DF-15 vähäglukosinolaattisia lajikkeita.

Span-Torch rypsirouheen rehuarvoksi sialla saatiin kahtena peräkkäisenä vuonna 0.80 ja $0.79 \mathrm{ry} / \mathrm{kg}$ ka. Rypsikakun $8 \%$ korkeampi rasvapitoisuus ja rasvan hyvä sulavuus yhdessä muiden aineosien vähän parantuneen sulavuuden kanssa nosti kakun ry-arvon noin $30 \%$ vastaavan rouheen arvoa paremmaksi. Runsas- ja vähäglukosinolaattisten lajikkeiden sulavuudessa ja maittavuudessa ei ollut eroa, mutta vuosien välillä todettiin maittavuudessa selvä ero. 
Rypsi/rapsi -ohradieeteillä saatiin sioille hyvät typpitaseet, 20.4-22.2 g N/pv. Rouheen ja kakkujen raakaproteiinin biologiseksi arvoksi tuli 67-68.

Pässeillä Span-Torch rouheen rehuarvoksi todettiin 0,91 ry/kg ka ja $309 \mathrm{~g} s r v / \mathrm{kg} \mathrm{ka}$. Rypsikakun sulavuus oli lähes sama kuin vastaavan rouheen, mutta $8 \%$-yksikköä korkeampi rasvapitoisuus nosti sen ry-arvoa noin $20 \%$. DF-15 kakun sulavuus oli vähän Span-Torch kakun sulavuutta parempi $(\mathrm{P}<0.05)$.

Pässit söivät rouhetta ja kakkua hyvällä halulla $32 \%$ :n osuutena rehusta, kun taas sioille samat rehut kelpasivat vain vastahakoisesti $20 \%$ :n osuutena. Kahtena edellisenä vuonna siat söivät vastaanpanematta rouheita $30 \%$ :n osuutena rehusta. 